\title{
LENGTH-WEIGHT RELATIONS OF 14 ENDEMIC FISH SPECIES FROM THE UPPER YANGTZE RIVER BASIN, CHINA
}

\author{
Jinming WU ${ }^{1}$, Lei LI ${ }^{1,2}$, Hao DU ${ }^{1}$, Hui ZHANG ${ }^{1}$, Chengyou WANG ${ }^{1}$, and Qiwei WEI ${ }^{1 *}$ \\ ${ }^{1}$ Key Laboratory of Freshwater Biodiversity Conservation, Ministry of Agriculture of China, Yangtze River \\ Fisheries Research Institute, Chinese Academy of Fishery Sciences, Wuhan 430223, China \\ ${ }^{2}$ College of Fishery, Huazhong Agricultural University, Wuhan 430070, China
}

Wu J., Li L., Du H., Zhang H., Wang C., Wei Q. 2013. Length-weight relations of 14 endemic fish species from the upper Yangtze River basin, China. Acta Ichthyol. Piscat. 43 (2): 163-165.

\begin{abstract}
Length-weight relations were estimated for 14 endemic fish species of the upper Yangze River, namely Sinogastromyzon szechuanensis Fang, 1930; Jinshaia sinensis (Sauvage et Dabry de Thiersant, 1874); Megalobrama pellegrini (Tchang, 1930); Coreius guichenoti (Sauvage et Dabry de Thiersant, 1874); Rhinogobio cylindricus Günther, 1888; Rhinogobio ventralis (Sauvage et Dabry de Thiersant, 1874); Procypris rabaudi (Tchang, 1930); Ancherythroculter kurematsui (Kimura, 1934); Ancherythroculter nigrocauda Yih et Wu, 1964; Acrossocheilus monticola (Günther, 1888); Leptobotia elongata (Bleeker, 1870); Hemiculterella sauvagei Warpachowski, 1888; Hemiculter tchangi Fang, 1942; and Xenophysogobio boulengeri (Tchang, 1929). The a values obtained ranged from 0.006 to 0.023 , and $b$ values ranged from 2.955 to 3.377 . The $t$-test results indicated the first seven species grew isometrically and the other 7 species grew allometrically.
\end{abstract}

Keywords: Length-weight relations, LWR, endemic fish, upper Yangtze River

The Yangtze River is the third longest in length- and ninth largest river in the world. The upper Yangtze River flows from Yibin to Yichang with a length of $1040 \mathrm{~km}$ and more than 50 tributaries joining the mainstream. Because of its meteorological, hydrological, physiographical, and geological diversity, the basin is characterized by pronounced habitat heterogeneity and considered a biodiversity hot spot for fish conservation (Dong 2003). There are about 286 species and subspecies including 124 endemic species distributing in the upper Yangtze basin (He et al. 2011).

In fish biology, length and weight are two basic morphological traits at the individual- as well as at the population level. The weight of fishes is closely related to their length, and there are three somatic growth types for most fish species: isometric (all fish dimensions increase at the same rate), positive allometric (a fish increases more in weight than predicted by its increase in length) and negative allometric (a fish increases less in weight than predicted by its increase in length) (Froese et al. 2011). Length-weight relation (LWR) has been used widely for fishery management and conservation. It provides information on the condition factor and somatic growth type (isometric or allometric) of fish species (Le Cren 1951, Bagenal and Tesch 1978, Bolger and Connolly 1989). It enables the calculation of individual weight from its length, estimating age structure, weight growth rate, and stock assessment. This relation has also been used for comparison of species growth between sexes, different seasons and regions (Froese 2006). Up to now, LWRs of 3584 species can be checked in FishBase (Froese and Pauly 2012)

Our current knowledge on the biological traits of Chinese freshwater fishes is still very limited (Fu et al. 2003). In particular, LWRs are only known for some commercially important fishes such as: Cyprinus carpio L.; Carassius auratus (L.); Ctenopharyngodon idella (Valenciennes, 1844); etc. In this study, we estimated the LWR parameters for 14 endemic fish species collected from the upper Yangtze River and its tributaries. Also, to the best of our knowledge, this study presents the first reference on the LWRs worldwide for these species.

The collections were made periodically between October 2011 and July 2012 in the mainstream of the upper Yangtze River and its seven tributaries. Three types of fishing gear were used in the sampling course, gill net $(1.5,4,5$, and $5.5 \mathrm{~cm} \mathrm{mesh})$, trap, and longline hooks. Sampled fish were identified to species according to references (Ding 1994, Yue 2000), and then measured to the nearest $0.1 \mathrm{~cm}$ standard length $(L)$, weighed $(W)$ with a digital balance with the accuracy of $0.1 \mathrm{~g}$. Length and weight data were pooled together in each species without

\footnotetext{
* Correspondence: Dr. Qiwei WEI, 湖北省武汉市东湖新技术开发区武大园一路8号, 中国水产科学研究院长江水产研究所, 430223, 中国, China, phone: +86 (027) 81780118, e-mail: weiqw@yfi.ac.cn.
} 
sexing or discrimination as to sampling sites and time. A $\log -\log$ plot of data was done for all species; outliners were identified and removed (Froese 2006). The parameters $a$ and $b$ of relations of the form

$$
W=a L^{b}
$$

were estimated through a logarithmic transformation (Tesch 1971, Cone 1989), i.e.,

$$
\log W=\log a+b \log L
$$

Intercept $a$ and slope $b$ were estimated by ordinary least squares regression and 95\% confidence limits of $a$ and $b$ were calculated. The $b$-value was tested by $t$-test to check whether the growth of each species is isometric $(b=3)$, positive allometric $(b>3)$ or negative allometric $(b<3)$.

A total of 3782 specimens covering 2 families, 10 genera, and 14 species were caught from upper Yangtze River and its tributaries. The species studied were: Sinogastromyzon szechuanensis Fang, 1930; Jinshaia sinensis (Sauvage et Dabry de Thiersant, 1874); Megalobrama pellegrini (Tchang, 1930); Coreius guichenoti (Sauvage et Dabry de Thiersant, 1874); Rhinogobio cylindricus Günther, 1888; Rhinogobio ventralis (Sauvage et Dabry de Thiersant, 1874); Procypris rabaudi (Tchang, 1930); Ancherythroculter kurematsui (Kimura, 1934); Ancherythroculter nigrocauda Yih et Wu, 1964; Acrossocheilus monticola (Günther, 1888); Leptobotia elongata (Bleeker, 1870); Hemiculterella sauvagei Warpachowski, 1888; Hemiculter tchangi Fang, 1942; and Xenophysogobio boulengeri (Tchang, 1929) Thirty two outlines were excluded according to the $\log -\log$ plot, and regressions were made for a total of
3750 individual fish specimens. The species name, sample size $(n)$, length and weight ranges, intercept $a$, slope $b$, $95 \%$ confidence interval of $a$ and $b$, coefficient of determination $\left(r^{2}\right)$, growth type and $t$-test value were summarized in Table 1 .

The sample size ranged from 57 individuals for Acrossocheilus monticola to 670 for Coreius guichenoti. Procypris rabaudi recorded the highest maximum length of $49.0 \mathrm{~cm}$ followed by Megalobrama pellegrini $(40.5 \mathrm{~cm})$, Leptobotia elongata $(34.7 \mathrm{~cm})$ and C. guichenoti $(34.5 \mathrm{~cm})$. Overall, the values for the intercept $(a)$ remained within the range of $0.007-0.023$. The values of $b$ rose from 2.955 in Xenophysogobio boulengeri to 3.377 in Rhinogobio ventralis. The majority of LWRs were highly significant with the coefficient of determination greater than 0.93 . But the $r^{2}$ value for $A$. monticola was a bit low (0.863); part of the reason may be the small sample size. Seven of fourteen species showed positive allometric growth $(b>3$, $P<0.05$ ), namely Sinogastromyzon szechuanensis, Megalobrama pellegrini, Coreius guichenoti, Rhinogobio ventralis, Ancherythroculter nigrocauda, Hemiculterella sauvagei, and Hemiculter tchangi. The other seven species (Jinshaia sinensis, Rhinogobio cylindricus, Procypris rabaudi, Ancherythroculter kurematsui, Acrossocheilus monticola, Leptobotia elongata, and Xenophysogobio boulengeri) grew isometrically.

The somatic growth of fishes is influenced by a number of factors such as sex, gonad maturity, growth phase, season, and stomach fullness (Tesch 1971). These factors were not accounted for in the presently reported study. In

\begin{tabular}{|c|c|c|c|c|c|c|c|c|c|c|c|c|c|}
\hline \multirow{2}{*}{ Species } & & \multicolumn{2}{|c|}{ Length $[\mathrm{cm}]$} & \multicolumn{2}{|c|}{ Weight $[\mathrm{g}]$} & \multicolumn{5}{|c|}{ Parameters of LWR } & \multirow{2}{*}{$\begin{array}{l}\text { Growth } \\
\text { type }\end{array}$} & \multicolumn{2}{|c|}{$t$-test $\left(H_{0}: b=3\right)$} \\
\hline & & Range & Mean & Range & Mean & $a$ & $95 \% \mathrm{CI}$ of $a$ & $b$ & $95 \% \mathrm{CI}$ of $b$ & $r^{2}$ & & $t$-value & $P$-value \\
\hline sze & 173 & $3.0-9$ & 5.2 & 20.1 & 3. & 0.016 & $0.014-0.018$ & 3.189 & 3.104 & 0.970 & $\mathrm{~L}$ & 4.407 & $<0.001$ \\
\hline $\sin$ & 80 & $4.3-14.3$ & 8.9 & -40.9 & 12.1 & 0.011 & $0.008-0.016$ & 3.099 & $2.933-3.265$ & 0.946 & $1 \mathrm{~T}$ & 1.181 & $>0.1$ \\
\hline M. pel & 117 & $4.0-40.5$ & 12.8 & $0.9-435.4$ & 73.6 & 0.013 & $0.011-0.014$ & 3.181 & $3.127-3.235$ & 0.992 & $\mathrm{p}-\mathrm{AL}$ & 8.452 & $<0.001$ \\
\hline C. gui & 670 & $3.6-34.5$ & 14.4 & $0.8-865.6$ & 91.5 & 0.015 & $0.014-0.015$ & 3.030 & $3.018-3.042$ & 0.997 & 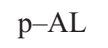 & 4.665 & $<0.01$ \\
\hline R. cyl & 564 & $5.2-28.2$ & 15.3 & 50.0 & 53.8 & 0.013 & $0.012-0.014$ & 3.010 & .049 & 0.976 & IS & 0.502 & $>0.5$ \\
\hline$R$. ven & 282 & $3.0-23.4$ & 16.1 & $0.2-253.9$ & 91.7 & 0.007 & $0.006-0.007$ & 3.377 & $3.328-3.425$ & 0.985 & $\mathrm{p}-\mathrm{AL}$ & 15.141 & $<0.001$ \\
\hline P. $r a b$ & 151 & $3.8-49.0$ & 17.3 & $1.9-2550.0$ & 238.4 & 0.023 & $0.017-0.032$ & 3.014 & $2.895-3.133$ & 0.943 & IS & 0.230 & $>0.5$ \\
\hline A. kur & 436 & $5.2-20.3$ & 13.5 & $2.2-143.1$ & 36.7 & 0.014 & $0.012-0.016$ & 2.990 & $2.937-3.044$ & 0.965 & IS & 0.360 & $>0.5$ \\
\hline A. $n i$ & 109 & 4.3 & 13. & 0 & 43 & 0 . & 0 . & 3. & 1 & 0 & 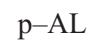 & 4.620 & $<0.001$ \\
\hline A. mon & 57 & $8.0-15.5$ & 11.7 & $13.6-100.3$ & 42.8 & 0.018 & $0.009-0.040$ & 3.137 & $2.803-3.471$ & 0.863 & IS & 0.810 & $>0.1$ \\
\hline L. elo & 133 & $3.5-34.7$ & 17.9 & $0.3-518.1$ & 87.2 & 0.011 & $0.009-0.013$ & 3.015 & $2.951-3.078$ & 0.985 & IS & 0.462 & $>0.5$ \\
\hline H. sau & 217 & $5.8-13.6$ & 10.7 & $2.0-42.2$ & 17.9 & 0.006 & $0.005-0.008$ & 3.308 & $3.187-3.428$ & 0.931 & $\mathrm{p}-\mathrm{AL}$ & 5.017 & $<0.001$ \\
\hline H. tch & 555 & $6.1-23.5$ & 12.5 & $2.6-201.6$ & 30.1 & 0.011 & $0.010-0.012$ & 3.051 & $3.008-3.094$ & 0.972 & $\mathrm{p}-\mathrm{AL}$ & 2.320 & $<0.05$ \\
\hline$X$. bou & 206 & $2.6-13.4$ & 7.2 & $0.3-50.0$ & 8.1 & 0.019 & $0.017-0.021$ & 2.955 & $2.897-3.013$ & 0.980 & IS & 1.520 & $>0.1$ \\
\hline
\end{tabular}

Length-weight relations of fishes captured in the upper Yangtze River

Length = standard length; S. sze = Sinogastromyzon szechuanensis; J. sin= Jinshaia sinensis; M. pel =Megalobrama pellegrini; C. gui = Coreius guichenoti $R$. cyl = Rhinogobio cylindricus $;$. ven $=$ Rhinogobio ventralis $;$ P. rab $=$ Procypris rabaudi; A. kur = Ancherythroculter kurematsui; A. nig = Ancherythroculter nigrocauda; A. mon = Acrossocheilus monticola $;$ L. elo = Leptobotia elongata $;$ H. sau = Hemiculterella sauvagei; H. tch = Hemiculter tchangi; X. bou = Xenophysogobio boulengeri; $\mathrm{p}-\mathrm{AL}=$ positive allometric; $\mathrm{IS}=$ isometric. 
addition, selective gear, small sampling size, and narrow length range could have biased and significantly influenced the parameter values of LWRs (Froese et al. 2011). In this study, sample size of most specie (except Jinshaia sinensis and Acrossocheilus monticola) were above 100, and measured individuals covered juveniles to adults, thus, the LWRs results of these 14 endemic fishes were credible and served as baseline data for endemic fishes management and conservation.

\section{ACKNOWLEDGEMENTS}

This study was sponsored by the Director Fund of Yangtze River Fisheries Research Institute (SZ2012-01). The authors wish to thank the colleagues: Yuntao Zhou, Long Ren, Meng Yang, Zhihua Hu, and Minjun Zhang for their assistance in the fieldwork. We also thank the anonymous reviewers for their helpful comments and review of this manuscript.

\section{REFERENCES}

Bagenal T.B., Tesch F.W. 1978. Age and growth. pp. 101-136. In: Bagenal T. (ed.) Methods for assessment of fish production in fresh waters. IBP handbook 3. Blackwell Science Publications, Oxford, UK.

Bolger T., Connolly P.L. 1989. The selection of suitable indices for the measurement and analysis of fish condition. Journal of Fish Biology 34 (2): 171-182. DOI: $10.1111 /$ j.1095-8649.1989.tb03300.x

Cone R.C. 1989. The need to reconsider the use of condition indices in fishery science. Transactions of the American Fisheries Society 118 (5): 510-514. DOI: 10.1577/15488659(1989) $118<0511:$ TNTRTU $>2.3 . C O ; 2$

Ding R.H. 1994. [The fishes of Sichuan.] Sichuan Publishing House of Science and Technology, Chengdu, China. [In Chinese.]
Dong Z.R. 2003. [Diversity of river morphology and diversity of biocommunities.] Journal of Hydraulic Engineering 11: 1-6. [In Chinese.]

Froese R. 2006. Cube law, condition factor and weight-length relationships: history, meta-analysis and recommendations. Journal of Applied Ichthyology 22 (4): 241-253. DOI: 10.1111/j.1439-0426.2006.00805.x

Froese R., Pauly D. (eds.) 2012. FishBase. [version 10/2012] http://www.fishbase.org.

Froese R., Tsikliras A.C., Stergiou K.I. 2011. Editorial note on weight-length relations of fishes. Acta Ichthyologica et Piscatoria 41 (4): 261-263. DOI: 10.3750/AIP2011.41.4.01

Fu C., Wu J., Chen J., Wu Q., Lei G. 2003. Freshwater fish biodiversity in the Yangtze River basin of China: patterns, threats and conservation. Biodiversity and conservation $\mathbf{1 2}$ (8): 1649-1685. DOI: 10.1023/A:1023697714517

He Y., Wang J., Lek S., Cao W., Lek-Ang S. 2011. Structure of endemic fish assemblages in the upper Yangtze River Basin. River Research and Applications 27 (1): 59-75. DOI: 10.1002/rra.1339

Le Cren E.D. 1951. The length-weight relationship and seasonal cycle in gonad weight and condition in the perch (Perca fluviatilis). Journal of Animal Ecology 20 (2): 201-219.

Tesch F.W. 1971. Age and growth. Pp. 99-130. In: Ricker W.E. (ed.) Methods for assessment of fish production in fresh waters. Blackwell Scientific Publications, Oxford, UK.

Yue P.Q. 2000. [Fauna Sinica (Osteichthyes): Cypriniformes, III.] Science Press, Beijing, China. [In Chinese.]

Received: 5 December 2012

Accepted: 26 March 2013

Published electronically: 30 June 2013 